\title{
Epidemic Field Investigation as Applied to Allegations of Chemical, Biological, or Toxin Warfare
}

\author{
Peter Barss Montreal General Hospital and McGill University, Canada
}

\begin{abstract}
It is proposed that the established epidemiologic framework normally used for investigation of civilian epidemics can usefully be adapted to provide a more structured approach to future investigations of allegations of chemical, biological, or toxin warfare. Using this framework, investigations of such allegations during the past decade are reviewed. These investigations took place during the yellow rain affair in Laos and Kampuchea, the Iran-Iraq war, and the Iraq-Kurd war. Further allegations are likely and will require investigation.
\end{abstract}

Peter Barss is a consultant physician with the Injury Prevention Program at the Department of Community Health of the Montreal General Hospital, 980 rue Guy, Suite 300A, Montreal, Quebec H3H 2K3, Canada. He is also at McGill University. He worked for ten years in rural areas of Angola and Papua New Guinea, and published numerous articles on the epidemiology and prevention of injuries among subsistence villagers. Dr. Barss has conducted an epidemiologic investigation of a severe environmental epidemic of respiratory illness among the civilian crew of a U.S. Naval Oceanographic vessel in the Canary Islands. $\sim$ HEMICAL, BIOLOGICAL, and toxin warfare have reemerged as real or imagined threats to public health in developing countries during the past decade. Chemical weapons have been shown to have devastating effects when used against defenseless civilians or poorly-equipped third-world armies and guerrilla fighters (Spiers, 1986). Allegations by various developing countries that chemical or biological weapons have been used against them may be expected to increase, as more countries develop the capacity to manufacture chemical (including toxins) and biological agents, and delivery systems. Some allegations will be made in good faith and others simply for propaganda.

While the preparation and enforcement of international agreements to deal with chemical, biological, and toxin warfare (CBTW) involve the coordinated efforts of policy makers and politicians at the highest national and international levels, investigations of alleged violations ultimately rely upon the results of scientific field studies, which are frequently conducted under difficult and often primitive and dangerous conditions. If the results of unreliable or invalid studies are given undue weight, serious errors may be made by policy and decision makers. The political and health consequences may be unexpected and severe.

This paper proposes that the investigation of an alleged outbreak of CBTW should be conducted, whenever possible, in accordance with the well-tested steps

Acknowledgments The author was supported during this work by a Medical Research Council of Canada Fellowship for Health Professionals. Professor Raymond Zilinskas, of the Johns Hopkins School of Hygiene and Public Health, encouraged the preparation of this paper and provided invaluable information and advice. Professor Matthew Meselson of Harvard University made helpful comments on the manuscript and provided detailed information about the yellow rain affair. Dr. Johan Lundin, Head of the SIPRI CBW Program, provided a useful critique of several technical matters. Dr. Gordon S. Smith, Dr. Knut Ra, and Dr. Alexander Langmuir, of the Johns Hopkins School of Hygiene and Public Health, provided helpful comments. The Verification Research Unit of the Arms Control and Disarmament Division of the Canadian Department of External Affairs provided essential documents and information. An earlier version of this paper received the 1990 Graduate Student Award for the Outstanding Paper in Politics and the Life Sciences; the encouragement and financial support of the Association for Politics and the Life Sciences are gratefully acknowledged. 


\section{Giving undue weight to unreliable studies may lead to serious errors by policy makers with unexpected political and health consequences}

that guide the standard epidemiologic investigation of an outbreak of disease or injuries. Epidemiology has been defined as "the study of the distribution and determinants of health-related states and events in populations, and the application of this study to the control of health problems" (Last, 1983:32-33). An epidemic has been defined as "the occurrence in a community or region of cases of an illness, specific health-related behavior, or other health-related events clearly in excess of normal expectancy" (Last, 1983:32).

Epidemic theory and practice and the steps in an outbreak investigation as adapted to CBTW are described. This discussion is followed by a short review and analysis, using the epidemiologic framework, of three investigations of alleged CBTW that have taken place since 1979. These investigations were conducted by a multilateral organization (the United Nations), a government (the United States) and a private organization (the Physicians for Human Rights). The analysis considers whether the usual steps in an epidemic investigation were followed and, if not, whether any significant omissions in the investigation contributed to later problems in satisfactorily resolving the allegations of CBTW.

The international agreements (relatively few) that have been negotiated during the past century in the ongoing effort to control the use of chemical and biological weapons are outlined. A few of the most significant incidents in the history of CBTW in developing countries are also reviewed.

While the use of appropriate epidemiologic methodology appears to be important for the investigation of all serious allegations of CBTW, it will be essential where novel agents are suspected. Recent advances in biotechnology have made the development and use of new agents of CBTW more feasible (Geissler, 1990a, 1990b; Spiers, 1989; Zilinskas, 1990). While the epidemiologic investigation of incidents of CBTW involving known agents is often relatively straightforward, investigation of incidents involving completely new agents with unknown properties is likely to be much more demanding. This extra demand could necessitate the use of multiple teams of highly trained epidemiologists and other scientists, together with appropriate laboratory backup.

An appreciation for the potential complexity of such an undertaking may be gained by reviewing the original accounts of the civilian investigations that led to the discovery of the agent of Legionnaires' disease in the United States (see page 9 below). Similarly, the investi- gations of several international teams were needed to disprove conclusively allegations by the United States of mycotoxin warfare in Southeast Asia.

\section{Methods}

The major incidents of verified or alleged CBTW in developing countries were identified by referring to historical accounts in the publications of the Stockholm International Peace Research Institute (SIPRI, 1989:99$128 ; 1971: 125-130)$ and other resources (Spiers, 1986, 1989; Geissler, 1986; Robinson, 1986:6, 46-52). These incidents were reviewed to identify those cases in which investigations to verify the allegations had been made by scientific teams. Three such significant incidents were found to have been investigated and reported. Further details were sought about methods.

- Information about yellow rain was obtained by reviewing several of the many published accounts, including detailed reports of the Canadian investigations provided by the Canadian Department of External Affairs. Visits were made to the United States chemical weapons research center at Edgewood Arsenal and to the U.S. Army Medical Research Institute of Infectious Diseases at Fort Detrick. Discussions with staff, including a member of the original U.S. medical team that investigated the yellow rain incident in 1979, were helpful in obtaining additional information about the U.S. investigation.

- Information about the United Nations (UN) investigations of the multiple allegations of CBTW use in the Iran-Iraq war was obtained by reviewing the annual indices of the UN Security Council and General Assembly reports. The actual reports of the investigating teams were then obtained from the UN library in Washington.

- Information about the investigation of allegations of CBTW against Kurdish refugees in Iraq was obtained from a published article by the Physicians for Human Rights (Hu, Cook-Deegan, and Shukri, 1989). Background material was obtained from a report to the Committee on Foreign Relations of the U.S. Senate (Galbraith and Van Hollen, 1988).

\section{International agreements}

A number of international agreements have been negotiated in an attempt to restrict the use of chemical and biological weapons. The process began in 1868 with the Declaration of St Petersburg. A conference of the major European powers in 1874 issued the Declaration of Brussels forbidding the use of poisons and poisoned weapons. Next came the Hague Peace Conference of 
1899 , during which all participating powers, with the exception of the United States, signed the Hague Declaration, "agreeing to abstain from the use of projectiles the object of which is the diffusion of asphyxiating or deleterious gases" (Scott, 1909:155).

A conference organized by the League of Nations led to the drafting and signing of the 1925 Geneva Protocol, which prohibits "the use in war of asphyxiating, poisonous, or other gases, and of bacteriological methods of warfare" (League of Nations, 1929). The Protocol was ratified by all major powers with the exception of Japan and the United States, who did not ratify it until 1970 and 1975 respectively (Geissler, 1986).

The Protocol banned the use of such agents in warfare, but it did not limit their production. There are no provisions for investigation and verification of violations, nor for punishment of offending nations. Some countries, most notably the United States during the Vietnam War, have interpreted the Protocol as not prohibiting the use in war of herbicides or of chemical harassing or riot control agents such as tear gas. As of 1990, 130 countries were parties to the Protocol (U.S. Arms Control and Disarmament Agency, 1990:10-18).

The next major international agreement was the 1972 Biological Weapons Convention, which came into force in 1975 (Geissler, 1990a). The development, storage, production, or use for the purposes of warfare of any microbial or biological agent or toxin was prohibited (Geissler, 1986). Article VI states that any State Party to the Convention may lodge a complaint with the Security Council of the United Nations alleging a violation of the Convention. Such a complaint should include "all possible evidence confirming its validity, as well as a request for its consideration by the Security Council." In addition, Article VI declares that "each State Party to this convention undertakes to cooperate with any investigation which the Security Council may initiate...."

As of September 9, 1991, 118 countries were State Parties of the Convention, and were thus bound by its provisions after signing and ratifying or acceding (Biological Weapons Conference, 1991). Representatives of another 21 governments had signed the Convention, but their governments had not yet ratified or acceded to it. China, the United States, and the USSR all ratified the Convention. However, a number of important countries

\section{Since 1975, negotiators have tried to improve mechanisms for verification of compliance, to eliminate existing stockpiles, and to end the development and production of chemical weapons}

have not done so, including among others, Egypt, Indonesia, and Syria. Israel has neither signed nor ratified. Iraq signed in 1972, but ratified only in 1991. The Convention does not include any means of enforcement, or indeed of ensuring compliance with investigations $(\mathrm{Zi}$ linskas, 1986).

Since 1975, negotiators have tried to improve mechanisms for verification of compliance, to eliminate existing stockpiles, and to end the development and, production of chemical weapons. These negotiations have been conducted by the UN Conference of the Committee on Disarmament and by its successor, the Committee on Disarmament (Robinson, 1986), now known as the Conference on Disarmament. While multilateral negotiations are considered to have been most effective, bilateral and regional meetings have also been a useful part of this process.

\section{Developing countries}

Chemical weapons have tended not to be decisive battlefield weapons when used by developed countries against other developed countries (Moon, 1988; Spiers, 1986; SIPRI, 1971). They have been difficult to deploy successfully because of problems with the delivery of an effective dose to an enemy supplied with protective equipment, and the results have therefore been somewhat unpredictable in battle. The possibility of retaliation has also been a deterrent. However, in developing countries, troops and civilians frequently lack any protective equipment, and the effects are often much worse.

The Italians under Mussolini's fascist regime made the first major deployment of chemical weapons against a developing country in Abyssinia (Ethiopia) during 1935-36 (Spiers, 1986). The main agent used was mustard gas, which severely affected the Ethiopian soldiers since they had no protective equipment and were mostly barefoot. They had no chemical weapons of their own with which to retaliate.

The Japanese made extensive use of both biological weapons and chemical weapons (including tear gas, arsenite, and mustard gas) against poorly protected Chinese troops from 1937 to 1945 (Spiers, 1986; SIPRI, 1971). New information continues to emerge, since many of the Japanese records of human experiments that were carried out with biological warfare agents at their biological warfare research unit in Manchuria (Unit 731) were secretly obtained by General MacArthur and the United States military in exchange for non-prosecution of the principal Japanese researchers. Information about these records was suppressed until recently (Williams and Wallace, 1989; T.V.S., 1985). There were no systematic investigations of the Italian and Japanese uses of chemical and/or biological weapons at the time of the incidents. 
The next major, well-documented use of chemical agents was by the United States and the South Vietnamese, who made repeated and extensive use of chemical riot control agents and herbicides against troops, civilians and the environment in South Vietnam from 1961 to 1970 (Spiers, 1989; SIPRI, 1971; Orians and Pfeiffer, 1970). Since chemicals were openly used in Vietnam, an investigation was unnecessary to ascertain that they were being used, although the conditions of use of riot control agents, especially in closed tunnels and villages and during offensive operations, were highly controversial (SIPRI, 1971; Spiers, 1989).

The United States claimed at the time that the use of such chemicals was not prohibited by the 1925 Geneva Protocol. This viewpoint was seriously challenged in a 1969 resolution of the General Assembly of the United Nations (General Assembly, 1970). Others have also questioned the U.S. claims (Hu, Fine et al., 1989). A recent U.S. government document, on the other hand, provides a more charitable view of these activities (U.S. Arms Control and Disarmament Agency, 1990:10-18).

Egypt is reported to have used chemical weapons repeatedly against Royalist forces and civilian villagers in Yemen from 1963 to 1967 (Spiers, 1989; Schmidt, 1968:257-273). An investigation was carried out by physicians of the International Committee of the Red Cross in Yemen in 1967 (Spiers, 1989; Schmidt, 1968). This investigation included interviews with survivors concerning 75 deaths, medical examinations of four survivors, and examination of a corpse four days after burial. Since there is relatively little documentation available for this and other reports of CBTW during the conflict between Egypt and Yemen, they will not be discussed.

The major allegations of CBTW use since the Vietnam war have included U.S. accusations of possible toxin warfare by the USSR and its allies against the Hmong in the hills of Laos and Kampuchea; and Iranian and Kurdish accusations of the use of chemical agents by Iraqi troops, both externally against Iranian soldiers and civilians and internally against guerrillas and civilians of their own Kurdish minority. Since these three episodes were investigated by teams of scientists, including physicians, they were selected for review in order to highlight the importance of using an epidemiological framework for the investigations and to indicate the potential consequences of failing to adhere to the well-tested traditional steps of an epidemic investigation. These episodes have already been reported upon extensively. Only those details relevant to the purposes of this paper will be recapitulated.

\section{Epidemic theory and practice}

An epidemic is the occurrence of health events in excess of what is normally expected. Health events include mortality (death) and morbidity (injury or disease). If a serious disease is unexpected in an area, a single case may be sufficient to trigger an epidemic investigation by public health agencies, as, for example, with botulism or rare cases of encephalitis.

In chemical warfare with known synthetic agents, the occurrence of a single well-documented death or injury-with recovery of the agent in samples-may be sufficient to support an allegation of a violation of the 1925 Geneva Protocol (although additional welldocumented cases will naturally provide even more convincing evidence). In cases involving naturally occurring biological or toxin agents, proof of use may require the accumulation of more extensive evidence, especially if disease or toxicity caused by the agent occurs naturally in the area of alleged use.

For many of the small epidemics that occur in civilian life, immediate steps to control the epidemic are taken by local health officials on the basis of relatively limited and preliminary evidence, although occasionally conclusive scientific proof or political involvement may be needed. The control and prevention of outbreaks of CBTW, however, generally require relatively clear-cut and indisputable scientific evidence. The concerted international efforts that are needed to effectively deal with a nation-user of CBTW call for a solid consensus of heterogeneous groups of national and multilateral policy and decision makers. Such a consensus is unlikely to be achieved if the results of the investigation appear scientifically equivocal or politically biased.

The necessary data may include indirect evidence obtained by interviews and by medical examinations of victims and witnesses, and/or direct evidence provided by recovery of any agents or munitions at the site of an attack. Ideally, the investigators would interview everyone in the population concerned, both those who are ill and those who are not.

Since for reasons of time and cost this is often not possible, an awareness of the statistical principles of random sampling is important to avoid bias when choosing a sample of subjects and/or controls for interviews and examinations. This is particularly important when direct evidence, as provided by samples of the alleged agent, is unavailable due to inaccessibility or delay, and when the signs and symptoms are not definitive for a known agent. In all such cases, the evidence must be collected, assembled, and objectively reviewed to determine whether the observed patterns of morbidity and/or mortality are characteristic of a known agent and not readily explicable by other diseases or intoxications. Two important instruments that should be considered are the epidemic curve and a comparison of the attack rates in individuals with different exposures.

The epidemic curve is prepared by plotting on a graph the date and time of onset of each case. A case is a diseased, injured, or poisoned person, as defined by a 


\section{Most outbreaks of CBTW will involve agents that are well known, but investigating cases involving unfamiliar agents will necessarily be far more complex and extensive}

case-definition. The case-definition lists the symptoms, signs, and/or laboratory findings that are needed to include or exclude an individual as a case. An existing case-definition may sometimes be suitable. However, it is often necessary to establish a working case-definition for the purposes of the investigation. If there has been a known exposure to an agent, the epidemic curve makes it possible to calculate the mean, median, and range of the interval from the time of exposure until the onset of symptoms and signs (in the case of infectious agents, this interval is known as the incubation period). This information provides a valuable clue to the identity of agents, be they chemical, biological, or toxin.

The pattern of the curve may also help to distinguish outbreaks that have resulted from a common exposure to an agent at a single point in time (for example, by proximity to the explosion of a single shell containing a labile or volatile agent) from those that have resulted from an ongoing exposure (for example, from repeated exposure to food, water, air, or soil contaminated with an agent). In the case of an infectious agent, secondary spread from person to person may also be suggested by the appearance of the epidemic curve (for further discussion and illustrations of typical epidemic curves, see Kelsey, Thompson, and Evans, 1986:220-235).

The attack rate measures the proportion of a group affected over an interval of time by disease or injury, as established by the case-definition. Rates can be compared between subgroups with different characteristics (as defined by specific exposures or demographic characteristics such as age, sex, or residence) to determine those characteristics that are associated with the presence or absence of disease or injury. The strength of the observed associations can be measured using standard statistical tests.

Most outbreaks of CBTW will involve agents that are well known. For example, the principal agents used in recent attacks by Iraq against Iran were mustard gas (in use since 1917) and organophosphate nerve agents (related organophosphorous compounds have been in use as insecticides since just after World War II). However, some cases may involve unfamiliar agents. Investigations in these cases will necessarily be far more complex and extensive, as in the case of the civilian investigation of an epidemic of an unknown disease that ultimately became known as Legionnaires' pneumonia. This disease event- ually was found to be caused by bacteria that multiply in warm water and that are aerosolized by the cooling towers or water systems of modern buildings (Kelsey $e t$ al., 1986:242-253; Fraser et al., 1977).

As in any scientific investigation, nothing should be taken for granted at the inception. A first and vital step in an investigation is to establish whether an epidemic actually exists. This may be relatively simple or extremely difficult, depending upon the normal expectancy of the observed events in the population. Clinical findings from certain well-known chemical agents are highly characteristic and may be virtually diagnostic (for example, blistering of the skin from mustard gas, and paralysis from organophosphorus nerve agents). With an obvious case of poisoning by mustard gas, one case may constitute an epidemic. However, with a disease or injury that is defined by a complex set of symptoms and signs potentially due to any number of unknown agents, the background rate of the disease or injury in the population must be known or determined in order to decide whether the observed rate is, or is not, an epidemic.

Bias may be introduced by failure to observe this systematic sequence of steps, and will affect the scientific integrity of the investigation. Bias will be more likely to occur if military or political leaders, or the investigators, uncritically assume that an agent has been used, or have their own particular reasons for wanting to prove this to be so. In certain situations, based upon an uncritical assumption that an agent of CBTW has been used, the initial investigation may inappropriately be delegated to chemical or military experts who are deployed simply to determine which chemical or other agent has been used. However, what may be needed, at least during the initial stages, is an epidemiological investigation to provide the most probable explanation for complex patterns of morbidity and mortality. The patterns of morbidity and mortality that are observed, recorded, and analyzed by the epidemiologist may provide evidence for the use of an agent of CBTW. On the other hand, they may equally well be explicable by any number of the complex combinations of diseases, nutritional deficiencies, intoxications, and stresses found in a population in a war zone, particularly in an impoverished developing country.

\section{Field investigation}

The most comprehensive guides to the conduct of investigations of alleged CBTW are reports prepared by teams of UN experts (Secretary-General, 1984a; SecretaryGeneral, 1988h; Secretary-General, 1989) and a handbook prepared by a Canadian government team (Government of Canada, 1985, 1987). Additional practical information is provided by another Canadian document, which reviews the Canadian field investigations of the yellow rain incident (Humphreys and Dow, 1982). 
Table 1. CBTW field investigation

\begin{tabular}{|c|c|c|}
\hline Phase & Item & Description \\
\hline \multirow[t]{4}{*}{ Preparation } & 1. Request for an investigation & To UN Security Council or Secretary-General \\
\hline & 2. Response to the request & By UN Secretary-General \\
\hline & 3. Selection of personnel & $\begin{array}{l}\text { Medical epidemiologist and/or toxicologist, chemist, } \\
\text { microbiologist, from neutral countries }\end{array}$ \\
\hline & 4. Preparation for the investigation & By the team of experts \\
\hline \multirow[t]{3}{*}{ Fieldwork } & 5. Determination of the existence of an epidemic & $\begin{array}{l}\text { Establish case-definition, conduct interviews of alleged } \\
\text { victims, carry out clinical examinations, interview } \\
\text { controls, check histories of different groups for } \\
\text { consistency }\end{array}$ \\
\hline & $\begin{array}{l}\text { 6. Collection of indirect or direct evidence of the agent } \\
\text { by biological sampling }\end{array}$ & Obtain samples from alleged victims and controls \\
\hline & $\begin{array}{l}\text { 7. Collection of direct evidence of the agent by } \\
\text { environmental sampling }\end{array}$ & $\begin{array}{l}\text { Obtain samples from soil and/or munitions; package } \\
\text { multiple samples for replication of analyses by } \\
\text { independent laboratories in different countries }\end{array}$ \\
\hline \multirow[t]{4}{*}{ Analysis and report } & 8. Analysis of data & $\begin{array}{l}\text { Orient data by time, place, and person; calculate attack } \\
\text { rates in cases vs. controls; plot epidemic curve; } \\
\text { consider the most probable agents; determine high-risk } \\
\text { subgroups }\end{array}$ \\
\hline & $\begin{array}{l}\text { 9. Collection of additional information needed to } \\
\text { complete investigation }\end{array}$ & \\
\hline & 10. Preparation of detailed report & \\
\hline & $\begin{array}{l}\text { 11. Control of the epidemic and implementation of } \\
\text { long-term prevention }\end{array}$ & $\begin{array}{l}\text { Organize international political action such as trade } \\
\text { embargos, cessation of foreign assistance, and } \\
\text { collaboration }\end{array}$ \\
\hline
\end{tabular}

These publications contain information about the general organization and conduct of an investigation, as well as specific information about the processing and transport of specimens. A technical document that provides guidelines for the transport of specimens has been prepared by the U.S. Army (U.S. Army, 1987).

The steps in conducting an epidemic investigation have been outlined by Gregg (1985:284-299). These have been amalgamated with some of the approaches suggested in the above documents, and with the practical field experiences described later in this article, to provide an 11 step framework for the investigation of an allegation of chemical or biological warfare. The steps in such an investigation may be divided into three general phases (see Table 1): preparatory steps, fieldwork, and analysis and reporting. There is sometimes overlap between the second and third phases, since preliminary analysis and reporting may need to be carried out in the field.

\section{Request for an investigation}

An official request provides the basis for an investigation. United Nations General Assembly Resolution 42/37C of November 30, 1987, and Resolution 44/115B of October 4, 1989, authorize the Secretary-General to investigate the alleged use of chemical or biological weapons on the basis of information brought to him by any member state. Member states may report any use of such weapons that is believed to constitute a violation of the 1925 Geneva Protocol or other relevant international law (Secretary-General, 1989). The information to be provided in such a report was outlined in Appendix I of a recent report of UN experts (SecretaryGeneral, 1989). According to Article 6 of the Biological Weapons Convention, the request for an investigation of alleged biological or toxin warfare is to be made to the Security Council of the United Nations by any State Party to the Convention that finds any other State Party acting in breach of obligations to the Convention. However, this mechanism for notification would be problematic when governments of countries that have not ratified the Convention choose to use such weapons against their own minority groups.

Political and diplomatic considerations in reporting and acting upon requests for investigation are paramount, as is the consent of any countries involved to admit the investigators. Without these critical steps, no official UN investigation can take place. However, in some circumstances, limited clandestine investigations by private groups or individual governments have been made.

\section{Response to the request}

The Secretary-General of the United Nations must decide quickly, preferably within 24 hours, whether or not to conduct an investigation. If the decision is to investigate, he or she must then assemble a team of investiga- 
tors with appropriate funding and clearances. UN General Assembly Resolutions 37/98D, 42/37C, and 44/115B empower the Secretary-General to investigate, with the assistance of appropriate experts, any complaint of the use of CBTW with which he is presented (Secretary-General, 1989; Robinson, 1986).

Advance preparation and speed are important, since clinical and chemical evidence tend to disappear rapidly. Whenever possible, a team should be dispatched within 48 hours of the decision to investigate, and preferably sooner. The investigators should be chosen from a list of experts on file who have been previously nominated by their own member countries. The Secretary-General must obviously consider the safety of the investigators in deciding when and where to send them. He has frequently supplied one of his own staff to accompany the investigators to handle diplomatic liaison during the investigation. At least two international laboratories, previously certified as capable of conducting analyses for suspected chemical, biological, or toxin agents, should be retained to conduct independent analyses.

\section{Selection of personnel}

The field team should generally include a medical epidemiologist, particularly in investigations in which alleged victims will be interviewed or examined. The epidemiologist would preferably be an individual familiar with CBTW agents and their clinical effects. He or she should also have experience with occupational and infectious (including tropical) diseases and field investigations of outbreaks. Postmortem examinations and sampling may occasionally be required. If access to locations of the alleged attacks is feasible, the investigative team may need to include a chemist, toxicologist, and/or microbiologist knowledgeable about CBTW agents, munitions, and personal protection. The team may have to investigate and sample the environment and munitions fragments for suspected agents and also carry out preliminary field identification of agents. A munitions expert should be able to recognize the typical appearance of standard chemical munitions and the soil craters caused by their detonation, and be able to distinguish them from high explosives and their effects. However, if new types of CBTW munitions have been developed secretly, they may be more difficult to recognize.

Other personnel may be added as dictated by the circumstances of the outbreak. In cases where access to the sites of alleged attacks for environmental sampling is not possible, only a medical epidemiologist may be needed to interview and examine victims in refugee camps or hospitals. A member of the SecretaryGeneral's staff would also normally accompany the group. The assistance of unbiased and patient interpreters will be essential if long and difficult interviews need to be conducted in an unfamiliar language.
When previously unstudied agents are suspected (for example, as a possible result of genetic engineering) much larger multidisciplinary teams may be necessary, as in the investigations of Legionnaires' disease.

\section{Preparation}

Before departing for the field, personnel of the investigative team should be assembled and their respective responsibilities made clear. Efforts should be made at this time to prepare a suitable draft questionnaire (a sample questionnaire is included as Appendix IX in Secretary-General, 1989), establish laboratory liaison, and arrange for the international transport of specimens with the appropriate quarantine authorities. Supplies will need to be gathered, including sample containers, cameras, personal protective equipment, and medical supplies. In-country liaison and assistance, official entry permits, and perhaps special life insurance for members of the team need to be in order. The availability of a previously prepared checklist and stockpiles of containers for specimen transport should help to prevent important omissions and speed the preparations.

\section{Determination of epidemic}

A simple case-definition (initially broad and allinclusive) must be rapidly developed so that potential cases and/or witnesses can be identified and investigated. The case-definition will be based upon the appropriate signs and symptoms as indicated by the circumstances and the suspected agent(s) (for example, blistering from mustard gas, miosis, profound salivation, twitching of minor muscles, cramps, and paralysis from nerve agents). A quick survey of the study population can then be made and a list prepared of the number of potentially affected individuals. This list should be used as a sampling frame from which an unbiased sample of individuals can be randomly selected for interviews, especially in those situations where the number of potentially affected individuals is too large to allow interviews of everyone.

Clinical interviews should then be conducted to obtain information such as the location, date, time, and nature of the alleged attacks (including a description of the delivery system for the agent: artillery shell, helicopter bomb, etc.); the demographics of the victim or person interviewed (age, sex, previous address, and occupational status, including whether military or civilian, etc.); and the signs and symptoms after the attack. The date and location of the interview should also be recorded. The questionnaire may need to be revised after the first few interviews to incorporate additional questions dictated by the specific circumstances. Local language translations may also be necessary.

When patients have already been admitted to an existing health facility, some of the necessary information 
may be obtained by review of clinical data with local health workers. Nevertheless, independent verification of cases is important. When there are large numbers of hospitalized casualties, verification could include the examination of a random sample of the allegedly affected individuals. Otherwise, direct examination in the field or in refugee camps may be necessary. A random sample or cluster sample of victims and/or witnesses for interview and/or examination may need to be taken, depending upon the numbers and the available time. Victims and/or witnesses should be interviewed at different locations, if possible, and their responses cross-checked for consistency. Suitable controls, or unaffected witnesses of attacks, should be identified and randomly selected for interviews, as indicated by the circumstances.

In the case of vague or multiple ill-defined symptoms, it may be necessary to interview a sample of controls to define the background prevalence of the alleged signs and symptoms in the study population. Alternatively, it may be possible to obtain this information from the local health authorities. It is important to identify cultural differences regarding time and colors. Villagers may not recall calendar dates or exact times, and, in some cultures, only a limited number of colors are defined by a language. A non-biased and patient interpreter, and some degree of privacy, will be essential in order to collect valid data on sensitive issues. Color charts and calendars of important local events may be helpful in defining colors of agents and dates of attacks.

\section{Biological sampling}

Biological samples should be obtained from patients. For example, complete blood counts, including white cell counts, are useful in identifying hematologic toxicity due to mustard gas, while red blood cell cholinesterase levels may remain depressed or absent for weeks or even months after exposure to organophosphate nerve agents (Rosenstock and Cullen, 1986). Samples from as many patients as possible should be obtained, and samples from unexposed controls of similar demographic characteristics must also be obtained, if at all possible.

Direct evidence of agents such as mustard gas may sometimes also be obtained in various biological samples from patients. For example, mustard gas has been extracted from hair samples (Secretary-General, 1986). Sampling may also be necessary during postmortem examinations.

\section{Environmental sampling}

When access to an attacked area is possible, field samples should be obtained from the environment and/or unexploded or fragmented munitions. Samples are most frequently obtained from soil, air, or fragments of munitions (Secretary-General, 1988e, 1988g, 1987). When the location or presence of a chemical agent is not obvious, especially if some time has elapsed since an attack, portable instruments known as Chemical Agent Monitors are used to screen the soil surface and munitions for traces of agents. Samples can then be taken from the most promising areas (Secretary-General, 1986, 1988c). The instruments should be calibrated against known concentrations of the suspected agents prior to field use.

Control samples, from similar environments known not to have been subjected to CBTW attacks, should also be taken for comparison. Appropriate protective equipment and decontamination procedures will be necessary. Samples (in triplicate) will need to be packaged for transport to designated independent international laboratories that are equipped to handle synthetic chemicals, natural toxins, or infectious agents, as indicated by the initial findings in the field. It is important that samples be divided and analyzed in more than one laboratory, since there can be significant differences in reports for the same material from different laboratories. Preliminary field analysis may be possible with simple reactive strips or more sophisticated chemical detection equipment such as analytical kits or sensing instruments (including the Chemical Agent Monitor).

Samples should be handled and transported in a secure manner that will withstand international scrutiny. The condition of the seals on the containers should be noted and recorded on arrival at the laboratories, to detect any evidence of tampering. Technical details concerning the collection and analysis of samples have been discussed extensively in several references (SecretaryGeneral, 1984a, 1989; Government of Canada, 1985, 1987; Humphreys and Dow, 1982; U.S. Army, 1987; Ministry of Foreign Affairs of Finland, 1982, 1983, 1990). While the collection and submission of suitable negative control samples is important, it has also been recommended that samples "spiked" with the suspect agents should be prepared and submitted along with field samples in order to test the laboratories' ability to detect the agents (Government of Canada, 1985). The transport of small quantities of chemical agents into the field to add to samples presents obvious logistical difficulties, and does not appear to have been used in most of the recent field investigations in the Middle East. However, the submission of positive samples as a check on the laboratory could be organized in other ways.

\section{Analysis of data}

The data should be organized with respect to time, place, and person. For example, simple summary tables should be prepared of the demographic characteristics of victims and also of the time, place, and method of attack. Population subgroups that show increased susceptibility to toxic effects or infection because of age, sex, or occupational status should be identified. Mapping the loca- 
tion of exposures may be useful. If available, data from controls should also be summarized in tables and compared with data from victims. This should allow calculation of attack rates as discussed above. Hypotheses should be formulated and tested for consistency with the available data. Alternative diagnoses should be considered and excluded as indicated by the evidence. The case-definition should be refined and narrowed to exclude unlikely cases.

An attempt should be made to determine the source of the outbreak. It might result from a common source (simultaneous exposure to an agent from a point source such as an air attack, or possibly ongoing exposure from a common vehicle such as poisoned food, water, or a ventilation system), or from propagation (secondary spread of an infectious agent from the original casualties to new victims).

The epidemic curve should be plotted, and the mean, median, and range of the interval from exposure until the onset of clinical effects calculated to help identify the agent and mode of spread to the affected individuals. Additional information should be obtained from international experts by telephone as required, depending upon the nature of the preliminary findings. The preliminary results should be communicated, as indicated, to the organization that initiated the investigation.

\section{Additional information}

In some cases, additional affected individuals or controls may need to be examined or interviewed. Reexaminations or reinterviews may also be necessary to obtain additional details as the investigation proceeds and new hypotheses are formulated. Further environmental or patient sampling may likewise be needed. If the initial investigations implicate novel biological or chemical agents with previously undescribed properties, additional teams of experts may need to be called upon to carry out pathological examinations, animal experiments, or other laboratory investigations to characterize and isolate the agent.

\section{Detailed report}

Adequate time should be allowed upon return from the field to obtain laboratory results and expert consultations, and to enter, analyze, and write up data from interviews, examinations, and samples. The report must be completed in a manner that will guarantee that it can withstand careful scrutiny by policy makers and other scientists in the international community.

\section{Control and prevention}

Detailed consideration of this step goes beyond the scope of this paper. In civilian epidemics, the investiga- tive team is often empowered to recommend and even implement interventions to interrupt the epidemic, sometimes before the investigation has been completed. However, in certain types of epidemics, there are important political considerations in planning and implementing interventions, as, for example, in the current epidemic of acquired immuno-deficiency syndrome (AIDS). In incidents of CBTW, the investigators would obviously have little or no power to develop or implement interventions, since these efforts are conducted mainly at a political and diplomatic level, albeit sometimes with consultation from appropriate technical experts.

If an allegation is substantiated, further aggression may be deterred via concerted international political action, such as through economic sanctions, export controls, international condemnation, etc. An example would be the types of activities undertaken against Iraq after the invasion of Kuwait but prior to the attack led by the United States. Such responses were unfortunately never tested as a deterrent to the earlier Iraqi attacks with chemical weapons on Iranians and Kurds. The use of legal approaches to modify undesirable behaviors of governments has been described by Fisher (1981), who has also outlined methods of negotiation as developed by the Harvard Negotiation Project (Fisher and Ury, 1983). If such efforts fail, the country that has been attacked may eventually retaliate in kind, leading to further exchanges of CBTW. In other circumstances, genocide may go unpunished and further use of CBTW or other unsavory activities may thereby be encouraged.

\section{Medical investigations}

Three armed conflicts during the 1980 s led to medical investigations carried out by the United States government, the United Nations, and by private organizations. All have been at least briefly described in the medical literature.

\section{Yellow rain in Indochina}

The United States publicly declared in a 1981 press conference that the USSR and its Asian allies had used trichothecene mycotoxins against the Hmong in Laos and Kampuchea (Seeley et al., 1985). The allegations and the investigations upon which they were based have been extensively discussed in many publications (Spiers, 1989; Harris, 1987; Robinson, Guillemin and Meselson, 1987, 1990; Seeley et al., 1985; Ashton et al., 1983; Ashton et al., 1985; Humphreys and Dow, 1982). A brief chronology of the different yellow rain investigations is outlined in Table 2. Characteristics of the 1979 investigation by the United States are summarized in Table 3. 
Table 2. Chronology of yellow rain investigations

\begin{tabular}{ll}
1978 & $\begin{array}{l}\text { U.S. Embassy in Bangkok sends telegram to } \\
\text { Washington to report interviews with Hmong } \\
\text { refugees claiming to have witnessed chemical } \\
\text { and biological warfare in Laos }\end{array}$ \\
1979 & $\begin{array}{l}\text { U.S. State Dept and U.S. Army investigations } \\
\text { Haig, in Berlin press conference, accuses USSR of } \\
\text { toxin (trichothecene) warfare, stating that } \\
\text { trichothecenes do not occur naturally in SE Asia }\end{array}$ \\
1981 & $\begin{array}{l}\text { UN investigations - inconclusive } \\
1981-82\end{array}$ \\
1982 & $\begin{array}{l}\text { Schultz repeats accusations in U.S. State Dept } \\
\text { report; Haig repeats accusations in a report to } \\
\text { U.S. Congress } \\
\text { Canadian Defense Force epidemiological team } \\
\text { detects trichothecene mycotoxins in blood of } 5 \\
\text { controls, but not in 10 alleged victims } \\
\text { British defense force scientists detect large } \\
\text { quantities of pollen in environmental samples of } \\
\text { alleged toxin agent } \\
\text { U.S. university scientists determine that samples } \\
\text { of alleged agent are bee feces }\end{array}$ \\
\hline
\end{tabular}

In September, 1978, the first telegram reporting Hmong claims of chemical attacks was sent from the U.S. Embassy in Bangkok. After preliminary investigation in June, 1979 by representatives of the State Department (with interviews of $22 \mathrm{Hmong}$ ), a U.S. Army medical team was sent, in October, 1979, to a refugee camp on the Thai-Kampuchean border. From an informal discussion with one of the original members, it appears that this team was dispatched with the mission of identifying the CBTW agent that was being used, rather than with the objective of determining whether CBTW was, in fact, being used. This is an important distinction. As a result of this decision, several medical experts knowledgeable about specific agents were sent to the camp (Haig, 1982).

The group did not include a public health physician with specialized training in epidemiological outbreak investigation. It appears that the team, which had little or no prior experience in conducting extensive epidemiological interviews through interpreters in a developing country, were taken to a large refugee camp where they attempted to carry out detailed interviews under crowded and difficult conditions. A long questionnaire, which had been prepared by other parties back in the United States, was used. It proved to be ill-suited to the specifics of the investigation. The team worked mainly through camp interpreters, whose objectivity was open to question. The 31 interviewees were chosen by the Hmong leaders in the camps.

There was no attempt to use a statistical sampling strategy, to obtain independent controls, or to calculate an average and range for the incubation period (interval from exposure until the onset of signs and symptoms). Thus, no comparison of the attack rates between exposed and unexposed persons could be made, nor could the interval from exposure until symptoms be compared with those typical for known agents. There was no estab-
Table 3. 1979 Yellow rain investigations by U.S. government

$\begin{array}{ll}\text { Personnel } & \begin{array}{l}\text { U.S. State Department Officials and U.S. } \\ \text { Army medical team - no } \\ \text { epidemiologists } \\ \text { Refugee camps on Thai-Kampuchean } \\ \text { border }\end{array} \\ \text { Location } & \begin{array}{l}\text { Designed in U.S., but not by field team } \\ \text { Questionnaire }\end{array} \\ \text { Sampling } & \begin{array}{l}\text { None - interviewees selected by } \\ \text { Hmong leaders }\end{array} \\ \text { Controls } & \begin{array}{l}\text { None - thus no comparison of attack } \\ \text { rates or biological samples between } \\ \text { exposed and non-exposed }\end{array} \\ \text { Sample transport } & \text { Informal } \\ \text { Sample analyses } & \begin{array}{l}\text { U.S. laboratory (Univ of Minnesota) in } \\ 1981\end{array}\end{array}$

lished procedure for transporting samples, and at least some were apparently transported by such means as personal camera bags.

The initial analyses of the environmental samples for mycotoxins were carried out by a scientist in the United States. There was no submission of duplicates or triplicates to independent laboratories in neutral countries. Biological samples from patients were analyzed without suitable controls; biomedical and environmental controls were used only in later years. In a separate investigation, an autopsy was reportedly carried out under primitive conditions in the field by medical employees of the CIA.

On the basis of these rather shaky data and various military reports, serious public allegations were levelled at the USSR and its allies by U.S. Secretary of State Haig and his successor George Schultz (Haig, 1982; Schultz, 1982). It was alleged at that time that mycotoxins did not occur naturally in the area. However, in a subsequent investigation, a Canadian Defense Force epidemiological team detected mycotoxins in the blood of five control subjects, but in none of ten alleged victims of CBTW (Humphreys and Dow, 1982). Many samples from alleged attacks on Laos and Cambodia were analyzed in 1982 by the U.S. Army Chemical Systems Laboratory in Aberdeen, Maryland and by the Porton Down Laboratory in Great Britain. These independent analyses failed to find any trichothecene mycotoxins (Robinson et al., 1990). Extensive precautions are obviously necessary in laboratory analyses in order to avoid false positives (Meselson, 1985a).

It was noted in 1982 by British scientists that the environmental samples contained pollen. Subsequently, U.S. scientists were able to establish that the samples of the alleged chemical warfare agent were actually multiple droppings of bee excrement (Harris, 1987; Robinson et al., 1987; Seeley et al., 1985; Ashton et al., 1983, 1985). Matthew Meselson (of Harvard University) and his associates made important contributions to this work and helped to publicize the findings (Robinson et al., 1987; Seeley et al., 1985; Ashton et al., 1983). While this 
work was being carried out, it was discovered that Chinese scientists had independently published a report in 1977 describing their own investigation of episodes of yellow rain in China. On the basis of their investigations, they had proposed that yellow rain was bee excrement consisting mainly of pollen (Zhang Zhongying, 1986; Zhang Zhongying, Chen Yu-Ming, Chou Shu, and Li Min, 1977).

A UN team of experts had also been sent to the region in 1981 and 1982. During their two visits, the team was unable to gain entry to the area of alleged deployment of CBTW. They interviewed refugees and medical personnel in border areas in Thailand and collected samples provided by the refugees. Their findings were inconclusive, and they were unable to substantiate the United States' claims of CBTW (Harris, 1987; Spiers, 1986).

The findings of the initial investigations by the U.S. teams were rejected by the USSR (USSR, 1982), and were received with a certain amount of scepticism by the international community. The extensive and controversial use of chemical harassing agents and herbicides by the U.S. in Vietnam during the 1960s (Spiers, 1989; SIPRI, 1971; Orians and Pfeiffer, 1970) probably also detracted from the credibility of their findings. Most of the steps needed to conduct an epidemic field investigation of alleged CBTW, as outlined above, appear either to have been bypassed or inexpertly handled by the U.S. in the yellow rain affair. This led to an unnecessary heightening of tension and mistrust between the two superpowers, and ultimately resulted in substantial embarrassment to U.S. authorities. Exploratory data, barely adequate as a basis for the formulation of preliminary hypotheses, was accepted as scientific proof and then misused by political and military authorities in an attempt to embarrass the USSR and its allies.

It is to be hoped that a protocol has been developed for handling future investigations in a more scientific and impartial manner. However, the U.S. does not yet appear to have published a comprehensive epidemiological guide, of the type already prepared by the United Nations and Canada, for use in future investigations. It is also unfortunate that the authorities who initiated and carried out the early U.S. investigations of yellow rain have not yet published a critical review of their work. A frankly self-critical review of the U.S. government's role in this affair by the military physicians and scientists who were involved might help to end the irritation and controversy that still linger a decade later. Important errors need to be acknowledged and highlighted to avoid repetition by future investigators. The present approach of sweeping the matter under the rug and hoping that people will forget about it could be counterproductive.

In future episodes of presumed use of new and unusual agents, a rigorous investigation should be planned, including careful documentation of incubation periods (or intervals from alleged exposure to onset of illness)
Table 4. Alternative explanations for symptoms attributed to toxin warfare against Hmong

\begin{tabular}{ll} 
Tear gas & $\begin{array}{l}\text { Troops affected by tearing of } \\
\text { eyes, burning of nose, other } \\
\text { irritant effects }\end{array}$ \\
Allergic response to pollen & $\begin{array}{l}\text { Nasal secretions and } \\
\text { obstruction, watery and itchy } \\
\text { eyes, hoarseness, chest } \\
\text { tightness, shortness of breath } \\
\text { Intestinal bleeding, as recently } \\
\text { reported among refugees on } \\
\text { the Thai-Kampuchean border } \\
\text { Enteritis necroticans (pigbel) } \\
\text { Misreporting }\end{array} \quad$\begin{tabular}{l} 
occur health effects did not \\
\hline
\end{tabular} \\
\hline
\end{tabular}

and comparison of attack rates for symptoms and signs between the allegedly exposed and controls. While always desirable, the use of controls may be less than essential in cases where well-known chemical agents with typical, immediate, and dramatic effects are used, as in the Iran-Iraq war investigations. In the United States, teams with extensive overseas field experience in the investigation of outbreaks, such as the Field Services Division of the Centers for Disease Control, should be able to provide valuable assistance in the planning of future investigations.

The Epidemic Intelligence Service (EIS) of the United States Centers for Disease Control, founded by Dr Alexander Langmuir and funded by the government in 1951 during the Korean War, was established to provide not only trained staff to investigate civilian epidemics, but also epidemiological "detectives" to deal with the potential threat of biological warfare (Mullan, 1989:139-140; Langmuir, 1980; Langmuir and Andrews, 1952; Hepler, 1952; Langmuir, 1951). It is difficult to understand why the EIS, which still exists today, was not actively involved in the yellow rain investigations, especially during the critical initial field surveys.

Informal discussion with more recent EIS staff suggests that subsequent directors of the EIS were mainly concerned with the investigation of civilian epidemics, and were relatively uninformed with respect to epidemiological investigation of allegations of CBTW. In addition, the political and military authorities of the 1980s may have been unaware of the EIS's historic mandate for involvement in such investigations, and therefore neglected to actively seek its epidemiological expertise. An uncharitable observer, however, might conclude that objective, scientific scrutiny of shaky evidence would have been unwelcome to U.S. political and military authorities with their own agendas to pursue.

While the United States government was unable to prove its case for the hostile use of mycotoxins in Indochina, alternative theories could explain some of the symptoms that were alleged to have affected the Hmong (Table 4). The controlled interviews conducted by the 
Table 5. UN investigations of allegations of chemical warfare in the Iran-Iraq War, 1981-1988

\begin{tabular}{ll}
\hline Personne! & $\begin{array}{l}\text { International team, including a } \\
\text { preventive medicine physician (military), } \\
\text { toxicologist, chemical and/or munitions } \\
\text { experts, UN liaison } \\
\text { Iran, Iraq } \\
\text { Interviews, clinical histories, } \\
\text { examinations, biological and } \\
\text { environmental sampling } \\
\text { Nocation } \\
\text { Data } \\
\text { by lraq were well-known and } \\
\text { characteristic; high attack rates among } \\
\text { the exposed } \\
\text { Clinical reports and analyses of Iranians } \\
\text { evacuated to other countries for } \\
\text { treatment }\end{array}$ \\
Consistency & $\begin{array}{l}\text { Formal, sealed } \\
\text { Independent laboratories in Sweden and } \\
\text { Switzerland; also analyses in field }\end{array}$ \\
Sample transport &
\end{tabular}

Canadian team (Humphreys and Dow, 1982) describe at least one episode in battle where troops were affected by tears in the eyes, burning of the nose, and other symptoms. This suggests the irritating effects of a lachrymator (harassing agent or tear gas). Indeed, analyses of certain environmental samples from the sites of alleged attacks in Kampuchea by the Swedish National Defense Institute in 1982 detected CS2, the siliconized form of the riot control agent CS, but no trichothecenes (Meselson, $1985 b$ ). Smoke inhalation could also perhaps have accounted for some of the reported symptoms. Other outbreaks of illness in villagers, which occurred after showers of yellow rain, could have been symptoms of an allergic response. Increased nasal secretions, nasal obstruction, watery and itchy eyes, hoarseness, chest tightness, and shortness of breath were among the most common symptoms listed by the investigators.

These findings suggest that the large quantities of pollen showered onto villages by the defecating bees may have induced an acute allergic response in individuals already sensitized to local pollens. However, arguing against such an explanation is the fact that the pollen in bee feces is embedded in a sticky matrix (M. Meselson, personal communication, 1991). This could preclude the formation of a dust fine enough to become airborne and inhaled, although yellow rain in China was observed to become powdery after it was disturbed (Zhang Zhongying, 1986). Another possibility is that many of the alleged heaith effects of yellow rain never occurred.

Other findings described by U.S. investigators included symptoms of severe intestinal bleeding, as well as autopsy findings of necrosis of the intestines. Such findings could be compatible with, among other conditions, enteritis necroticans. This severe and frequently fatal illness is caused by a clostridial toxin produced by intestinal bacteria in populations that are under nutritional stress. It affected children and adults in Europe during wartime food shortages, and has been reported extensively from Papua New Guinea, where it is known as pigbel. Enteritis necroticans has also recently been reported from a refugee camp on the Thai-Kampuchean border, where it was diagnosed in at least 62 children, with a case fatality rate of $58 \%$ (Johnson et al., 1987).

\section{Iran-Iraq War}

Extensive use of chemical weapons by Iraq against Iranian troops and civilians was alleged by Iran in the 1980s. Iran reported 242 attacks with 44,000 victims from 1981 to 1988 (Iran, 1988). Late in the war, Iraq alleged that Iran had made a CBTW attack against Iraqi soldiers (Secretary-General, 1988a and b). Several investigations were initiated by the Secretary-General of the United Nations at the request of the governments involved in the hostilities. Most were conducted in Iran, with the cooperation of the Iranian authorities (SecretaryGeneral, 1984a, 1984b, 1986, 1987, 1988a-h).

These investigations (Table 5) were handled by international teams, members of which were selected from lists of European experts previously submitted by various UN member countries. The analyses of specimens were completed in duplicate by laboratories in different countries in Europe, these laboratories having been selected from lists of facilities previously nominated by member countries. Several of the teams included a preventive medicine physician (military) specializing in war injuries, or a medical toxicologist, together with various chemical and munitions experts as dictated by the circumstances and by their availability at the time. At least one investigation appears to have been conducted by a single medical expert.

All investigations included interviews, clinical examinations, and laboratory analyses of victims, while some also included environmental sampling of sites of alleged attacks and/or of chemica! munitions. Laboratory findings of depressed white blood cell counts and reduced cholinesterase levels, typical of the toxic effects of mustard gas and organophosphate nerve agents respectively, were described in some victims, and mustard gas was also extracted from biological samples such as human hair.

Immediate field evidence of the presence of chemical agents was provided on several occasions by Chemical Agent Monitors, and these results were later confirmed when environmental (soil and air) and munitions samples were found to be positive for chemical agents by independent laboratories in Sweden and Switzerland (Dunn, 1986; Andersson, 1986; Secretary-General, 1984b, 1986, 1987, 1988c, 1988e, 1988g). During these investigations, teams were accompanied by a representative of the UN Secretary-General, who handled diplomatic and administrative matters during the investigations. 
Table 6. 1988 investigation by physicians for human rights of alleged chemical attacks on Kurds in Iraq

\begin{tabular}{|c|c|}
\hline Personnel & $\begin{array}{l}3 \text { physicians }-1 \text { trained in public health, } 1 \\
\text { Kurdish speaker }\end{array}$ \\
\hline Location & Two refugee camps in Turkey \\
\hline Questionnaire & $\begin{array}{l}\text { Epidemiologic survey format, translated into } \\
\text { Kurdish }\end{array}$ \\
\hline Data & $\begin{array}{l}\text { Interviews, clinical examinations of all age } \\
\text { groups }\end{array}$ \\
\hline Controls & $\begin{array}{l}\text { Randomly selected, but only for videotaped } \\
\text { interviews }\end{array}$ \\
\hline Consistency & $\begin{array}{l}\text { Cross-checked between individuals and two } \\
\text { camps }\end{array}$ \\
\hline Samples & $\begin{array}{l}\text { No biological or environmental samples } \\
\text { obtained by original team; however, } \\
\text { mustard gas found in samples later } \\
\text { coliected inside Iraq by a reporter and the } \\
\text { Kurdistan Democratic party; analyses by two } \\
\text { British laboratories }\end{array}$ \\
\hline
\end{tabular}

In addition to the evidence provided by these formal investigations, corroboration came from a published clinical report of Iranians evacuated for treatment to other countries (Requena et al., 1988). The clinical evidence included biopsies and photographs of skin lesions typical of mustard gas. The results of biological samples of blood, urine, skin, hair, and gastric juice, together with photographs of skin lesions, from Iranians who were evacuated to Vienna, London, Lausanne, and Ghent, also confirmed the use of large (lethal) amounts of mustard gas and an organophosphate nerve agent such as tabun (Secretary-General, 1986:Add. 2). The interviews, clinical histories and examinations, direct and indirect evidence from clinical laboratory specimens, and direct evidence from environmental and munitions samples together provided convincing evidence of the repeated use of chemical weapons by Iraq against Iran.

The intervals from the time of exposure to the agents until the appearance of clinical symptoms were typical for the agents that were isolated, and the attack rates among the exposed were high. Because of the consistency of the various findings, and because of the manner in which the investigations were carried out, scientific and political controversy regarding the conduct and results of the investigations was avoided. Controls do not appear to have been used for interviews or for the analysis of specimens. However, because the clinical effects of the chemical agents that were used are well-known and unlikely to have resulted from other causes, and because the evidence from multiple investigations fits together in a consistent and convincing manner, the lack of controls does not appear to have prejudiced the credibility of the investigation.

While the investigations discussed above involved Iranian casualties, at one point in the war a UN team was called upon to visit both Iran and Iraq in rapid succession to investigate allegations of the use of chemical weapons by both sides (Secretary-General, 1987). A number of Iraqi soldiers appeared, on the basis of the findings of medical examinations, to have been affected by mustard gas and possibly by a pulmonary irritant. Traces of mustard gas were found in a shell crater near Basra, but the two empty artillery shells that were presented as evidence of chemical munitions did not have the chemicalresistant lining typical of chemical ordnance, nor was mustard gas detected in them. It was also noted that the craters were not typical of those caused by chemical weapons. Thus, the evidence presented to the UN investigating team did not provide convincing support for the Iraqi allegation of CBTW use by Iran; the observed medical findings could also have resulted from Iraqi troops having been inadvertently exposed to their own chemical agents.

\section{Alleged chemical attacks on Kurds in Iraq}

It has been alleged that the Kurdish minority in Iraq has been subjected to repeated chemical attacks by Iraqi troops, with an estimated 3,000-5,000 victims (possibly far more), including many civilians (Hay and Roberts, 1990; Lundin, 1989; Hu, Cook-Deegan, and Shukri, 1989; Galbraith and Van Hollen, 1988). An investigation by a privately funded group in the United States, Physicians for Human Rights, was carried out in October, 1988 (Table 6) after a UN-sponsored investigation was refused by both Iraq and its neighbor Turkey, where many of the Kurdish refugees were located (Hu, CookDeegan, and Shukri, 1989). This team consisted of three physicians, one of whom held a public health degree and another of whom spoke Kurdish.

The investigation centered around visits to two refugee camps in Turkey, and involved interviews of eyewitnesses to attacks, as well as videotaped interviews of eyewitnesses and randomly chosen controls. The interviews were carried out about six weeks after the alleged attacks, using an epidemiologic survey questionnaire translated into Kurdish. Refugees were assembled for possible interview by asking camp leaders and bystanders to gather former residents of villages where chemical attacks were alleged to have occurred.

Respondents were chosen to ensure representation of all age groups. They were then interviewed separately. Responses were later entered into a database and checked for consistency among individuals. All were consistent with attack by a chemical agent, and also appeared to be consistent with respect to important details. Information provided by refugees in the two separate camps was also cross-checked for consistency. Clinical findings in the form of healing skin wounds were observed in three individuals. The lesions appeared similar to those described after the use of mustard gas, but other causes could not be excluded. Because of time constraints, it was not possible to carry out a randomized 
sampling with interviews of controls; and, because of several weeks delay in getting to the camps, it was not possible to obtain useful clinical laboratory specimens from alleged victims. The investigators were unable to obtain environmental or munitions samples from sites of alleged attacks.

In November, 1988, however, a journalist from London, England, assisted by the Kurdistan Democratic Party, secretly entered Iraq. The visit occurred ten to twelve weeks after an alleged bombing attack on the Kurds (Hay and Roberts, 1990). Samples of bomb fragments and soil were collected from a ruptured bomb that was embedded in the ground. The samples were transported personally by the journalist to two laboratories in the United Kingdom: a commercial firm and the U.K. Ministry of Defence's Chemical Defence Establishment at Porton Down. Mustard gas and breakdown products were found to be present by both laboratories. The concentration was high in the soil despite the delay between the bombing and the sample collection. The authors attributed this persistence of the chemicals to low ambient temperatures, low rainfall, and the fact that the chemicals were buried beneath the surface.

A separate small investigation of an alleged poisoning of Kurdish refugees in a Turkish refugee camp was later carried out by a member of the Kurdish Scientific and Medical Association and a journalist (Ala'Aldeen et al., 1990). Poisoning of food by a nerve agent was suspected, and blood samples were taken from a number of sick individuals. Only a few samples could be smuggled out of the camp. Various tests were run on the samples in England. Only two samples were tested for cholinesterase levels, and this testing was done after five days of storage at room temperature. Low cholinesterase levels were reported; however, no samples from unaffected individuals appear to have been transported under similar conditions. Samples of bread tested negative for suspected agents.

The authors state that their results are suggestive of poisoning by a nerve agent; but, because of the limited nature of the investigation, the results are not conclusive. They did not provide epidemiologic details of the attack rate in different subgroups of the refugee population as related to exposures to different foods, nor other details such as the incubation period and pattern of spread. Such details, perhaps unavailable to the investigators during their brief visit, might have helped to substantiate the allegations of spread by a common vehicle such as poisoned food or water.

\section{Conclusion}

Recent field investigations of allegations of CBTW have tended to be delegated to medical epidemiologists and other scientists, with the support of sophisticated labor- atories in developed countries for the analysis of specimens. In situations where the use of new or unusual agents is suspected, the use of a rigorous epidemiologic approach will be especially important. It is essential that investigators who are selected to participate in such investigations possess the requisite skills and experience. However, it is equally important that they are seen to be impartial by all parties, especially if an international political consensus must be reached for effective disciplinary action against an offending country.

The principle "innocent until proven guilty" seems obvious enough. When it is forgotten or ignored in a scientific investigation, serious errors, embarrassment, and loss of credibility may result. Violation of this principle, together with the lack of involvement of epidemiologists, appears to have critically damaged early U.S. investigations of the yellow rain episode. Suggested priorities for improving future investigations of allegations of CBTW include:

- Use of a detailed epidemiological guide (e.g. UN, Canada) with protocols to assist future investigative teams

- Establishment of a standard protocol for early consultation with Epidemic Intelligence Service and/or Field Services Division of Centers for Disease Control or equivalent

- Development of an appropriate case-definition; plotting of the epidemic curve; comparison of symptoms, attack rates, and laboratory findings in alleged victims and randomly selected non-exposed controls

- Selection of a multilateral team of appropriate experts, preferably from neutral countries; designation of laboratories in neutral countries for analyses

- Impartial assessment of reports with objective standards as for any peer-reviewed scientific paper

- Implementation of more effective mechanisms to deal with offenders-e.g. total embargo on trade, cessation of all foreign assistance and collaboration

- Implementation of mechanisms to deal with refusal of countries to admit UN investigative teams-e.g. automatic censure and sanctions

Investigations of alleged offenses of CBTW that are organized, staffed, and funded by a multilateral body, such as the United Nations may have the greatest chance of success, particularly when carried out expeditiously within an appropriate epidemiologic framework. It is to be hoped that all nations will immediately notify the appropriate United Nations authority whenever they believe that such an investigation is warranted, and that they will provide the greatest possible support to UN teams. Investigation by UN teams is most desirable, since UN teams will generally be credible to the greatest number of nations.

An investigating team, however, can only provide 
technical results. It is up to the international body to decide whether a violation has occurred and to take appropriate action. If such decisions are made at a national level, as in the yellow rain case, they may often not be supported by other parties. More effective mechanisms to deal with offenders are urgently needed. Possibilities include a coordinated total embargo on trade and a halt to all foreign assistance and collaboration. Although repeated UN investigations during the Iran-Iraq war were successful in documenting the use of chemical weapons, they did not prevent the continued use of chemical weapons by Iraq. Failure by the world community of nations to take early and effective concerted action against well-documented violations of the Geneva Protocol may have emboldened Iraqi leaders to embark upon further undesirable and unsavory activities, such as the use of chemical weapons against their own Kurdish minority and, ultimately, the invasion of Kuwait with its attendant violence and loss of life.

It has been reported by U.S. scientists that the massive use of defoliant chemicals by the United States during the Vietnam war resulted in the estimated loss of over one-third of the country's mangrove forests (crucial for the sustenance of coastal food chains and for protection against flooding during storms) for perhaps the next century (Spiers, 1989; Orians and Pfeiffer, 1970). Extensive efforts at replanting mangroves may have accelerated this recovery (M. Meselson, personal communication, 1991). Nevertheless, the military and political leaders who authorized the use of chemicals, which arguably caused the most extreme environmental destruction of a country in the history of war, have not yet been brought to justice. A stronger and more effective international court of justice appears to be urgently needed in today's world. In order for such an organ to function fairly in all cases, it will be necessary for the superpowers as well as smaller countries to accept its verdicts, even when a decision appears to override their own immediate interests. Appropriate mechanisms for enforcing the court's decisions need to be devised and supported by all civilized nations.

A disturbing problem, which still awaits an international political or legal solution, has been the refusal by certain countries to admit UN teams to investigate allegations of chemical weapons use, especially when internal minority groups are affected. Genocide of relatively influential, wealthy, and vocal minorities, such as

\section{Regional negotiations and agreements may be a large step towards a global solution for the problem of chemical, biological, and toxin warfare}

the gassing of the Jews with Zyklon B (Trepman and Albeck, 1990), has received much publicity since the Second World War, and many offenders were eventually brought to trial through the efforts of "Nazi-hunters." However, too often the world's political leaders have chosen to ignore compelling evidence of mass murder. Examples include not only the genocide of Jews, gypsies and others during World War II, but also, since then, the slaughter of many less-influential minorities within developing countries.

A convenient excuse for inaction has frequently been an assumption that the populations of the affected countries must somehow resolve their own problems internally, even when they are being murdered on a wide scale by despotic regimes-which are, unfortunately, often sustained and abetted by strategic foreign aid (Overseas Development Council, 1985, 1988). The nations of the world should be able to devise an international system of justice to investigate such allegations promptly and competently, and to enforce nonviolent but potent international sanctions against flagrant offenders.

Although the alleged manufacture of chemical weapons by countries such as Iraq is undesirable, the secret development of nuclear weapons by Israel and South Africa may be a more serious long-term impediment to peace and stability in the region. It will probably be difficult to achieve effective agreements for the elimination of CBTW among developing countries and their more highly developed neighbors without links between the various treaties that are supposed to control these different weapons systems. A country such as Iraq is understandably reluctant to negotiate away weapons systems that it perceives as its only psychologically-effective deterrent to a nuclear attack by a potentially hostile neighbor such as Israel (which has neither signed nor ratified the Biological Weapons Convention).

The use of a nuclear bomb in the region by Israel, the United States, or others, with the potential for widespread and long-lasting contamination of the earth's surface, poses a far greater long-term hazard to the peoples of the world than the use by Iraq of chemical weapons, which have short term and local effects. Since at the present time regional and border conflicts account for much of the hostility and fear between nations, regional negotiations and agreements may be a large step towards a global solution for the problem of chemical, biological, and toxin warfare.

The findings of investigations by national teams are subject to bias and may be used for propaganda; they therefore may fail to move the international community to take effective action against alleged users of CBTW. However, military and medical experts from various countries can make valuable contributions as members of a multilateral team. Investigations by private teams may have to be conducted surreptitiously, and may be 
hampered by insufficient funding and/or the absence of official support. Thus, their findings may be less than definitive and thereby fail to bring about concerted international action against violators of international agreements.

If UN teams are denied access to an area, or if their results should be unconvincing or inconclusive, private investigations may be useful. The scientific community played a valuable role in resolving the yellow rain controversy, and the Physicians for Human Rights and others were able to carry out investigations when UN teams had been refused admission to Iraq and to Kurdish refugee camps in Turkey.

Recent outbreaks of chemical warfare have resulted in injuries to civilians as well as troops, thereby falling within the purview of public health. It would be unwise and even irresponsible to leave the investigation and scientific review of such incidents to military experts only. The number of agents that are regularly used is limited at the present time, and their toxicology is no more complex than that of many toxic chemicals used in industry and agriculture. Many aspects of the investigation of deaths and injuries caused by CBTW are similar to investigations of disease and/or injury caused by civilian epidemics, and civilian experts should be capable of active participation and/or critical review.

The need for logical, intelligent, and unprejudiced investigations by teams of scientists, mainly from neutral countries, is likely to continue for the foreseeable future. If political and military leaders wish to maintain their public credibility, they should not try to shield their data from objective scientific scrutiny by resisting its declassification. All investigations of alleged CBTW should be subject to the same impartial standards as any scientific investigation, and should adhere to standard protocols as outlined in this article.

\section{References}

Ala'Aldeen, D., J. Foran, I. House, and A. Hay (1990). "Poisoning of Kurdish Refugees in Turkey." [Letter] Lancet 2(335):287-288.

Andersson, G. (1986). "Analysis of Two Chemical Weapons Samples from the Iran-Iraq War." Nuclear, Biological, and Chemical Defense and Technology International 1:62-65.

Ashton, P.S., M. Meselson, J.W. Nowicke, J.P.P. Robinson, and T.D. Seeley (1985). "Chemical Warfare Evidence Unconvincing." [Letter] Nature 315:284.

Ashton, P.S., M. Meselson, J.P.P. Robinson, and T.D. Seeley (1983). "Origin of Yellow Rain." [Letter] Science 222:366-368.

Biological Weapons Conference (1991). "Convention on the Prohibition of the Development, Production and Stockpiling of Bacteriological (Biological) and Toxin Weapons and on Their Destruction." Third Review Conference of the Parties to the Convention on the Prohibition of the Development, Production and Stockpiling of Bacteriological (Biological) and Toxin Weapons and on Their Destruction, GE.91-72614, BWC/CONF.III/INF.1 (September 9):1-4.

Dunn, P. (1986). "The Chemical War: Journey to Iran." Nuclear, Biological, and Chemical Defense and Technology International 1:28-37.

Fisher, R. (1981). Improving Compliance with International Law.
Charlottesville: University Press of Virginia.

Fisher, R., and W. Ury (1983). Getting to Yes: Negotiating Agreement Without Giving In. New York: Penguin.

Fraser, D.W., T.R. Tsai, W. Orenstein, W.E. Parkin, J. Beecham, R.G. Sharrar, J. Harris, G.F. Mallison, S.M. Martin, J.E. McDade, C.C. Shepard, P.S. Brachman, and the Field Investigation Team (1977). 'Legionnaires' Disease: Description of an Epidemic of Pneumonia." New England Journal of Medicine 297:1189-1197.

Galbraith, P.W., and C. Van Hollen (1988). "Chemical Weapons Use in Kurdistan: Iraq's Final Offensive." Staff Report to the Committee on Foreign Relations, United States Senate (100th Congress, 2d Session). Washington: U.S. Government Printing Office, S. Prt. 100-148, 89-722 (October): 1-46.

Geissler, E., ed. (1986). Biological and Toxin Weapons Today. Stockholm International Peace Research Institute. Oxford: Oxford University Press.

Geissler, E., ed. (1990a). Strengthening the Biological Weapons Convention by Confidence-Building Measures. Stockholm Internation.al Peace Institute, SIPRI Chemical and Biological Warfare Studies, Oxford: Oxford University Press.

Geissler, E. (1990b). "Strengthening the Biological Weapons Convention: Comments on the Contributions of Marie Isabelle Chevrier and Lynn Marvin Hansen." Politics and the Life Sciences 9:122-126.

General Assembly (1970). "Question of Chemical and Bacteriological (Biological) Weapons." Resolutions adopted by the General Assembly during its Twenty-Fourth Session 16 September-17 December 1969. Official Records: Twenty-Fourth Session, Supplement No. 30 (A7630), Resolution 2603 (XXIV) (December 16):16-17.

Government of Canada (1985). Handbook for the Investigation of Allegations of the Use of Chemical or Biological Weapons. Ottawa (November): 1-174.

— (1987). "Background Study to the Handbook for the Investigation of Allegations of the Use of Chemical or Biological Weapons." Ottawa (September):1-62.

Gregg, M.B. (1985). "The Principles of an Epidemic Field Investigation." In W.W. Holland, R. Detels, and G. Knox, eds. Oxford Textbook of Public Health, Volume 3: Investigative Methods in Public Health. New York: Oxford University Press.

Haig, A.M. (1982). "Chemical Warfare in Southeast Asia and Afghanistan: Report to the Congress from Secretary of State Alexander M. Haig Jr." Washington: United States Department of State, special report no. 98 (March 22):1-32.

Harris, E.D. (1987). "Sverdlovsk and Yellow Rain: Two Cases of Soviet Noncompliance?" International Security 11(4):41-95.

Hay, A., and G. Roberts (1990). "The Use of Poison Gas Against the Iraqi Kurds: Analysis of Bomb Fragments, Soil, and Wool Samples." [Letter] Journal of the American Medical Association 263:1065-1066.

Hepler, J.M. (1952). "Biological Warfare Defense: 3. The State Sanitary Engineer's Viewpoint." American Journal of Public Health 42:239-240.

Hu, H., R. Cook-Deegan, and A. Shukri (1989). "The Use of Chemical Weapons: Conducting an Investigation Using Survey Epidemiology." Journal of the American Medical Association 262:640-643.

Hu, H., J. Fine, P. Epstein, K. Kelsey, P. Reynolds, and B. Walker (1989). "Tear Gas - Harassing Agent or Toxic Chemical Weapon?" Journal of the American Medical Association 262:660663.

Humphreys, G.R., and J. Dow (1982). "An Epidemiological Investigation of Alleged CW/BW Incidents in SE Asia." Ottawa: Directorate of Preventive Medicine, Surgeon General Branch, National Defence Headquarters (August 11).

Iran (1988). Conference on Disarmament Document CD/827. (April 11). Cited in (1989). Stockholm International Peace Institute. SIPRI Yearbook 1989: World Armaments and Disarmament. Oxford: Oxford University Press: 101.

Johnson, S., D.N. Taylor, R. Coninx, B.E. Eampokalap, R.A. Cooke P. Echeverria, S.R. Paul, J. Sakurai, P. Jimakorn, G.W. Lawrence, and P.D. Walker (1987). "Enteritis Necroticans Among Khmer Children at an Evacuation Site in Thailand." Lancet 2(8557):496-500.

Kelsey, J.L., W.D. Thompson, and A.S. Evans (1986). "Epidemic 
Investigation." In Methods in Observational Epidemiology. Oxford: Oxford University Press.

Langmuir, A.D. (1951). "The Potentialities of Biological Warfare Against Man: An Epidemiological Appraisal." Public Health Reports 66:387-399.

- (1980). "The Epidemic Intelligence Service of the Center for Disease Control." Public Health Reports 95:470-477.

Langmuir, A.D., and J.M. Andrews (1952). "Biological Warfare Defense: 2. The Epidemic Intelligence Service of the Communicable Disease Center." American Journal of Public Health 42:235-238.

Last, J., ed. (1983). A Dictionary of Epidemiology. Oxford: Oxford University Press.

League of Nations (1929). League of Nations Treaty Series. Vol 94.

Lundin, S.J. (1989). "Chemical and Biological Warfare: Developments in 1988." In Stockholm International Peace Institute. SIPRI Yearbook 1989: World Armaments and Disarmament. Oxford: Oxford University Press.

Meselson, M. (1985a). "Visit to Porton." [Memorandum]. Cambridge, MA: Harvard University (February 1).

(1985b). "Swedish Studies of Yellow Rain." [Memorandum]. Cambridge, MA: Harvard University (November 10).

Ministry for Foreign Affairs of Finland (1982). "Systematic Identification of Chemical Warfare Agents 2." Helsinki.

(1983). "Systematic Identification of Chemical Warfare Agents." Parts B.3 and B.4. Helsinki.

- (1990). "International Laboratory Comparison (Round-Robin) Test for the Verification of Chemical Disarmament." Part F.1. Helsinki.

Moon, J. (1988). "In the Shadow of Ypres: The Chemical Warfare Dilemma." Fitchburg State College Press. The Harrod Lecture Series, Vol. 10 (November 30):31-97.

Mullan, F. (1989). Plagues and Politics: The Story of the United States Public Health Service. New York: Basic Books.

Orians, G.H., and E.W. Pfeiffer (1970). "Ecological Effects of the War in Vietnam". Science 168:544-554.

Overseas Development Council (1985). "U.S. Foreign Aid in the 1980's." Policy Focus 4:1-6.

(1988). "Foreign Aid: The Reagan Legacy." Policy Focus 2:110.

Requena, L., C. Requena, M. Sanchez, G. Jaqueti, A. Aguilar, E. Sanchez-Yus, and B. Hernandez-Moro (1988). "Chemical Warfare: Cutaneous Lesions from Mustard Gas." Journal of the American Academy of Dermatology 19:529-36.

Robinson, J. (1986). Chemical and Biological Warfare Developments: 1985. Oxford: Oxford University Press. (Stockholm International Peace Research Institute).

Robinson, J., J. Guillemin, and M. Meselson (1987). "Yellow Rain: The Story Collapses." Foreign Policy (Fall):100-117.

-(1990). "Yellow Rain in Southeast Asia: The Story Collapses." In S. Wright, ed. Preventing a Biological Arms Race. Cambridge, MA: MIT Press.

Rosenstock, L., and M.R. Cullen (1986). "Pesticides and Related Substances." In Clinical Occupational Medicine. Philadelphia: Saunders.

Schmidt, D.A. (1968). Yemen: The Unknown War. London: The Bodley Head.

Schultz, G.P. (1982). "Chemical Warfare in Southeast Asia and Afghanistan: An Update." Washington: United States Department of State, special report no. 104 (November):1-12.

Scott, J. B. (1909). The Hague Peace Conferences of 1899 and 1907, Volume II: Documents. Baltimore, MD: The Johns Hopkins Press.

Secretary General (1984a). "Chemical and Bacteriological Weapons: Report of the Group of Consultant Experts Established in Pursuance of General Assembly Resolution 37/98D on Provisional Procedures to Uphold the Authority of the 1925 Geneva Protocol." New York: United Nations General Assembly, publication no. A/39/488 (October 2):1-80.

- (1984b). "Report of the Specialists Appointed by the SecretaryGeneral to Investigate Allegations by the Islamic Republic of Iran Concerning the Use of Chemical Weapons." New York: United Nations Security Council publication no. S/16433 (March 26):1. 28.

(1986). "Report of the Mission Dispatched by the Secretary-
General to Investigate Allegations of the Use of Chemical Weapons in the Conflict Between the Islamic Republic of Iran and Iraq." New York: United Nations Security Council report no. S/17911 (March 12); and Corr. 1, Add. 1, Add. 2.

(1987). "Report of the Mission Dispatched by the SecretaryGeneral to Investigate Allegations of the Use of Chemical Weapons in the Conflict Between the Islamic Republic of Iran and Iraq." New York: United Nations Security Council report no. S/18852 (March 8); and Add. 1.

(1988a) . "Report of the Mission Dispatched by the SecretaryGeneral to Investigate Allegations of the Use of Chemical Weapons in the Conflict Between the Islamic Republic of Iran and Iraq." New York: United Nations Security Council report no. $\mathrm{S} / 19823$ (April 25): 1-26.

- (1988b). "Report of the Mission Dispatched by the SecretaryGeneral to Investigate Allegations of the Use of Chemical Weapons in the Conflict Between the Islamic Republic of Iran and Iraq: Appendix II. Summary Report on Patients Examined by the Medical Specialist with Relevant Clinical Data." New York: United Nations Security Council, report no. S/19823/Add. 1 (May 10):1-55.

- (1988c). "Report of the Mission Dispatched by the SecretaryGeneral to Investigate Allegations of the Use of Chemical Weapons in the Conflict Between the Islamic Republic of Iran and Iraq." New York: United Nations Security Council, report no. S/20060 (July 20):1-23.

(1988d). "Report of the Mission Dispatched by the SecretaryGeneral to Investigate Allegations of the Use of Chemical Weapons in the Conflict Between the Islamic Republic of Iran and Iraq: Appendix III. Summary Report on Patients Examined by the Medical Specialist with Relevant Clinical Data." New York: United Nations Security Council, report no. S/20060/Add. 1 (August 2): 1-48.

(1988e). "Report of the Mission Dispatched by the SecretaryGeneral to Investigate Allegations of the Use of Chemical Weapons in the Conflict Between the Islamic Republic of Iran and Iraq." New York: United Nations Security Council, report no. S/20063 (July 25): 1-19.

(1988f). "Report of the Mission Dispatched by the SecretaryGeneral to Investigate Allegations of the Use of Chemical Weapons in the Conflict Between the Islamic Republic of Iran and Iraq: Appendix II. Summary Report on Patients Examined by the Medical Specialist with Relevant Clinical Data." New York: United Nations Security Council, report no. S/20063/Add. 1 (August 2):1-13.

- (1988g). "Report of the Mission Dispatched by the SecretaryGeneral to Investigate Allegations of the Use of Chemical Weapons in the Conflict Between the Islamic Republic of Iran and Iraq." New York: United Nations Security Council, report no. S/20134. (August 19):1-16.

-(1988h). "Chemical and Bacteriological (Biological) Weapons". New York: United Nations General Assembly, publication no. a/43/690. (October 26):1-42.

(1989). "Chemical and Bacteriological (Biological) Weapons: Report of the Secretary-General," including Annex I. "Report of the Group of Qualified Experts in Pursuance of General Assembiy resolution 42/37 C." New York: United Nations General Assembly, publication no. a/44/561. (October 4):1-52.

Seeley, T.D., J.W. Nowicke, M. Meselson, J. Guillemin, and P. Akratanakul (1985). "Yellow Rain." Scientific American 253(3):128-137.

Spiers, E.M. (1986). Chemical Warfare. Chicago: University of Illinois.

-(1989). Chemical Weaponry: A Continuing Challenge. New York: St. Martin's Press.

Stockholm International Peace Research Institute (SIPRI) (1971). The Problems of Chemical and Biological Warfare, Volume I: The Rise of CB Weapons. New York: Humanities Press.

(1989). SIPRI Yearbook 1989: World Armaments and Disarmament. Oxford: Oxford University Press.

Trepman, E., and J.H. Albeck (1990). "Perversions of Medical Technology." [Letter] Journal of the American Medical Association 263:1066.

T.V.S. (1985). "Unit 731 - Did the Emperor Know?" London: Television documentary produced by TVS International. 
U.S. Army (1987). "Management Procedures for Chemical and Biological (CB) Agent Sampling, Transport, and Evaluation." Aberdeen Proving Ground: Armament Munitions Chemical Command, Chemical RD\&E Center, report no. CRDEC-SP. 87023. (August):1-43.

U.S. Arms Control and Disarmament Agency (1990). Arms Control and Disarmament Agreements: 1990 Edition. Washington, D.C.: Department of State: $10-18 ; 129-139$.

U.S.S.R. Academy of Sciences, U.S.S.R. Ministry of Health (1982). Critique of the Report of the United States Department of State to the Congress of the United States entitled "Chemical Warfare in Southeast Asia and Afghanistan". New York: United Nations General Assembly, report no. A/37/233. (May 21):1-19.

Williams, P., and D. Wallace (1989). Unit 731: The Japanese Army's
Secret of Secrets. London: Hodder and Stoughton.

Zhang Zhongying (1986). "Yellow Rain: A Major International Debate of the 1980's." Ziran Zazhi [China] 9:122-125 [In Chinese: English translation provided to the author by M. Meselson]

Zhang Zhongying, Chen Yu-Ming, Chow Shu, and Li Min (1977). "A Study of the Origin and Pollen Analysis of 'Yellow Rains' in Northern Kiangsu." Kexue Tongbao [China] 22:409-412 [In Chinese].

Zilinskas, R.A. (1986). "Verification of the Biological Weapons Convention." In E. Geissler, ed. Biological and Toxin Weapons Today. Stockholm International Peace Research Institute. Oxford: Oxford Press.

(1990). "Biological Warfare and the Third World." Politics and the Life Sciences 9:59-76. 